\title{
Research on Cost of Fine Coal Enterprises Management
}

\author{
Cheng Ming-e ,Tang Yang \\ School of Economics and Management, Henan Polytechnic University, P.R.China,454003 \\ Cme331@hpu.edu.cn
}

\section{Keywords: Coal enterprises; The cost of fine ; Management}

\begin{abstract}
The elaborating m anagement, is through the rules of system atization and refinem ent, standardization, standardization, digital and inform ation technology, make the or ganization and management units accurate, ef ficient, collaborative, and continue to run. Cost of fine coal enterprises management will change the past single by the financial de partment management, regular accounting cost $\mathrm{m}$ anagement mode, gradually transformed into all-round $\mathrm{m}$ anagement together, runs throughout the whole process com prehensive cost dynamic management, go the way of fine control, coal enterpris es to adapt to the development of market economy changes, to further improve management connotation, thus prom ote enterprise comprehensive management upgrades and ensure bottom-up development.
\end{abstract}

\section{Introduction}

The body of the coal is our ener gy, coal industry is the basic industry of national econom $\mathrm{y}$. Over the years, the coal as a non-renewable resources, made great contribution to national economic take-off. But under the condition of $\mathrm{m}$ arket economy, in the face of in creasingly fierce market competition, the coal enterprise res ource waste, extensive management method, many problem $\mathrm{s}$ such as weak com petitiveness gradually expose d. Along with the constant development of coal enterprises in our country and the inform ationization level unceasing enhancem ent, enterprise's competition from price competition to cost managem ent direction development, enterprise only strengthen technology innovatio $\mathrm{n}$, efforts to reduce production costs, im prove market competitiveness is the only way to survival and development.

Whole process comprehensive cost dynamic management, take the path of fine coal enterprise cost management is the inevitable choice of the development of modern coal enterprises. Therefore, coal enterprises should renew the idea, overall planning, from planning through strategic $\mathrm{m}$ acro management to vigorously prom otes the micro management to the basis of innovation, go the way of fine management, to adapt to the developm ent of market economy changes, to further im prove management connotation, thus promote enterprise comprehensive management upgrades and ensure bottom-up development.

\section{What is the fine management of coal enterprises}

Fine management was based on the detaile $\mathrm{d}$ operation and $\mathrm{m}$ anagement of the basic characteristics, it is by improving the quality of em ployees, to overcom e inertia, drip control enterprises, strengthening links, collaboration $\mathrm{m}$ anagement chain connection, thus im prove enterprise overall management method. This is a change from extensive management to intensive management, from the traditional experience $m$ anagement to scientific management. Is implement of fine management of coal enterprises enhance core competitiveness, decided the future, the key to success is to promote optimization and upgrading of industrial structure, the objective need to take a new road to industrialization. Cost of high and low directly affect the enterprise the stand or fall of economic benefits, therefore, to strengthen cost management, reduce the cost of coal products, coal enterprise is the key to the surv ival and development, in to day's coal market coal enterp rise only strengthen enterprise cost management to realize the change of economic growth pattern, can really get development in competition.

Refinement of coal enterprise cost $\mathrm{m}$ anagement, it is in the process of coal production cost management system solve the cost formation of the various key links and the main control points, in the process of production and opera tion of cost occurs, the product of the formation of organized and systematic prediction, decision-making, budgeting, control, business accounting, analysis and assessment, evaluation and so on a series of scientific management. Through cost decisions 
determine the tar get cost, and come up with the best cost of tar get cost budget control schem e. Modern enterprise cost management should advance through cost prediction, decision management, through the budget and control things $m$ anagement, through the analysis of the accounting for management. Fine cost management is the coal enterprise in a market economy under the condition of the basic way to seek the highest efficiency.

\section{The problems existing in the coal enterprise cost management}

Coal enterprises in the process of economic growth mode from extensive to intensive changes, to establish modern enterprise system, the internal vigorously to implement target cost management, gradually break down cost, and obtained the certain effect, the co al enterprise economic benefit increased significantly, but with the safety in production, technology, personnel placem ent of spending increases, problems existing in the cost management of coal enterprises gradually exposed.

3.1 Cost $\mathrm{m}$ anagement concept should be stre ngthened. Enterprise decision-making and management to the im portance of cost $\mathrm{m}$ anagement has had a full unde rstanding, but at the grassroots area team, team, until the positions are not enough. Exist in the practical work, attaches great importance to the production cost, but ignore th e details of the cost m anagement, lack of full cost concept, lack of system cost control measures.

3.2 The cost control of breadth and depth is no t enough., on the breadth of the cost control of enterprise at present is mainly around the cost com ponents to control, and ignore the influence of external factors on the enterprise cost. Look from the depth, often only attaches great importance to the production process of savings, rather than to the cost and the technical, cost and safety, cost and quality on the best fit for control; Look from the breadth, nominal cost control, cost and technology, was not well play the role of technical work in cost control.

3.3Cost management method and means also is relatively backward. Although coal enterprises to establish the cost forecast, decision-m aking, planning, accounting, control, evaluation and cost analysis method of cost management system. But still stay on the cost accounting and cost analysis of simple, and less use of other m ethods. On cost management informationization level is not high, the cost managem ent is not scientific predic tion based on $\mathrm{m}$ arket information, analysis and decision-making.

\section{Implementation of fine cost management for coal enterprises}

Only coal enterprises to strengthen cost $\mathrm{m}$ anagement, cost management from the tactical and economical, by material type, account type for the center to the strategic, economic and technology, people-centered, can we truly achieve operational change change the wa y of econom ic growth, improve their competitiveness and meet the challenge of the market.

4.1 Improve the cost managem ent consciousness, establish level 4 cost responsibility center, strengthen the cost control at th e grass-roots level fine cost management ability. Set to a turn ing around as the core concept of cost control, the cadres at all levels and all kinds of professional and technical personnel to enhance co st consciousness, properly handle cost and technology, the relationship between the safety, quality, etc, Set up team, team, post the basic point of accounting control system. Around the budget in advance, the matter controls, afterwards analysis "of the production cost $\mathrm{m}$ anagement ideas, set up company, functional departm ents, teams, team or individual level 4 production cost $\mathrm{m}$ anagement system, realize fu lly the whole process comprehensive cost control, to achieve the unity of the responsibility, right,.

4.2 Implement budget control system, strengthen the objective cost $\mathrm{m}$ anagement. Combined with the enterprise's profit target and the target of cost control, de velop belongs to each cost center is reasonable, feasible and scientific cost control target and cost budget. To mobilize the enthusiasm of each cost center to reduce costs, but also according to th e production changing law with flexible goal cost control. Focus on refining the achievem ent of cost center at all levels, to ach ieve effective transfer cost pressure, make the cost management more targeted and effective.

4.3 The modern cost management method, achieve the fine $m$ anagement. With quantitative analysis, the detailed $\mathrm{m}$ easures, strengthen the responsibility, hardening of the rewards and punishments based on four aspects, with the transition of the function of the authority management, 
cost management process optimization control, the coordination of prod uction and operation, the economic and technological innovation as the $\mathrm{s}$ upport, through the integrated cost $\mathrm{m}$ anagement system function, optimized cost management operating mechanism, implements the comprehensive budget management, scientific decision-making, promote production monitoring cost management of each link, strengthening the management responsibility cost responsibil ity center, the overall efficiency of the implementation cost management improvement.

4.4 Strengthening responsibility, team, jobs, personal is the sm allest unit in the process of production, team operation personnel directly $i$ nvolved in the producti on process of various technical index regulation of thei $r$ actions directly related and in fluenced the process of $s$ mooth, efficiency of high and low , and the costs of all kinds of consumption. On the refinem ent management responsibility, therefore, focus on strengthening to the team , jobs, and personal responsibility. Do daily management standardization, and strict appraisal. Enterprise standardization is a work of science, technology and $\mathrm{m}$ anagement practices, on the basis of the com prehensive results of repetitive things and concepts through formulation, distribution and im plementation of standards, to achieve unity and standardization, in order to obtain the best benefit of the work.

4.5The frame support system. Fine coal enterprises cost control $\mathrm{m}$ anagement is a system atic project, to achieve ef fective control of cost, $\mathrm{m}$ ust construct a responsibil ity center, budget breakdown cost, function change, step by step c ontrol, coordination of production and operation, the operation of mass innovation and efficiency for the pillar of the whole s ecurity system. Change cost management mode, on the basis of the whole cost management, from top to bottom to form a kind of everyone involved, people management, so as to plug the loopholes in management, reduce the working cost.

\section{References:}

[1]Wuquanmin; Coal enterprise cost accounting and management discussion [J]; Modern eco nomic information; 10, 2011

[2] Chen Xiaoqing; Introduction to coal enterprise cost management [J]; Friends of the accounting; 24, 2011

[3]Yang Maoshan; Fine $\mathrm{m}$ anagement in the coal $\mathrm{m}$ ine safety training applic ation [J]; Heilongjiang science and technology information; 22, 2011

[4]Wang Zhongjiang; Zhao Mingxing;; Coal m ine electrical and mechanical safety in production of fine management $[\mathrm{J}]$; Science and technology information; 17, 2011

[5]Wang fang; Coal enterprise cost management refinement; Modern business; 11, 2011 